\title{
Aquatic invertebrates associated with bromeliads in Atlantic Forest fragments
}

\author{
Antonio Teixeira de Paula Júnior ${ }^{\text {* }}$, Beatriz Figueiraujo Jabour Vescovi Rosa ${ }^{1}$, Roberto Gama Alves ${ }^{I}$ \& \\ Alex Campos Divino ${ }^{I}$ \\ ${ }^{1}$ Universidade Federal de Juiz de Fora, Juiz de Fora, MG, Brazil \\ * Corresponding author: Antonio Teixeira de Paula Júnior e-mail: jrselterrocao@hotmail.com.br
}

JÚNIOR, A.T.P., ROSA, B.F.J.V., ALVES, R.G., DIVINO, A.C. Aquatic invertebrates associated with bromeliads in Atlantic Forest fragments. Biota Neotropica. 17(1): e20160188. http://dx.doi.org/10.1590/1676-0611-BN-2016-0188

\begin{abstract}
Forest fragments in the state of Minas Gerais contain a large number of Bromeliaceae genera, whose cisterns accumulate water and organic matter, providing shelter and food for a wide range of organisms. However, these fragments often consist only of small patches of vegetation, making the species more vulnerable to the effects of this landscape changes. This study aimed to test the effect of the distance to the edge and of the matrix type on the structure of aquatic invertebrate communities in four morphospecies of bromeliads. Samples were collected in Atlantic Forest fragments adjacent to pasture and planted forest areas, in a region of Serra da Mantiqueira, Brazil. Of the 147 bromeliads investigated, we found 35 taxa, among which the most abundant groups were Ostracoda (4,962 individuals), Culicidae (2,358), Tanypodinae $(1,164)$ and Scirtidae $(1,043)$. The richness of taxa and Shannon diversity of invertebrates were similar at different distances from the edge, with variation of richness between 17 and 23 taxa and diversity between 1.25 and 1.52. The composition of the fauna in the cisterns changed between some collection sections (A vs. C, C vs. D and D vs. F), irrespective of being close to or far from the edge. There was no variation of richness $(t=-1.145, d f=106, p=0.341)$ and diversity $(\mathrm{t}=1.376, \mathrm{df}=106, \mathrm{p}=0.429)$ among samples collected from fragments next to planted forest and pasture, likely because the bromeliads studied were located on hillsides above the canopy of planted forests, and subject to similar conditions to those found in the fragments next to pastures. The results demonstrate the importance of bromeliads in maintaining the richness and diversity of the invertebrates they harbor, even in altered landscapes exposed to extreme conditions such as fragment edges.
\end{abstract}

Keywords: Edge effect, phytotelma, invertebrates, remaining forest

\section{Invertebrados associados a bromélias em fragmentos de Mata Atlântica}

Resumo: Remanescentes florestais em Minas Gerais concentram grande número de gêneros de Bromeliaceae, cujos taques acumulam água e a matéria orgânica que servem de abrigo e fonte de alimento para uma grande variedade organismos. Entretanto, tais áreas têm sido reduzidas a pequenas manchas de vegetação, tornando as espécies mais vulneráveis aos efeitos decorrentes dessa modificação da paisagem. O presente estudo visou caracterizar a estrutura das comunidades de invertebrados aquáticos em quatro morfoespécies de bromélias. As amostras foram coletadas em fragmentos de Mata Atlântica em matriz de pastagem e floresta plantada, em uma região da Serra da Mantiqueira, Brasil. Nas 147 bromélias investigadas foram encontrados 35 táxons, entre os quais os grupos mais abundantes foram Ostracoda (4,962 individuals), Culicidae (2,358), Tanypodinae (1,164) e Scirtidae (1,043). A riqueza de táxons e diversidade de Shannon foram semelhantes em diferentes distâncias da borda, com variação entre 17 e 23 táxons e diversidade entre 1.25 e 1.52. A composição da fauna nos tanques variou entre algumas faixas de coleta (A vs. C, C vs. D e D vs. F), independentemente de estarem próximas ou distantes da borda. Não houve variação da riqueza ( $\mathrm{t}=-1.145$, $\mathrm{df}=106, \mathrm{p}=0.341)$ e diversidade $(\mathrm{t}=1.376, \mathrm{df}=106, \mathrm{p}=0.429)$ entre as amostras coletadas em fragmentos próximos à floresta plantada e pastagem, provavelmente devido às bromélias estudadas estarem localizadas em encostas acima do dossel das florestas plantadas, e sujeitas a condições semelhantes às encontradas nos fragmentos ao lado de pastagens. Foi possível demonstrar a importância das bromélias na manutenção da riqueza e da diversidade de invertebrados que abrigam, mesmo em paisagens alteradas e expostas a condições extremas, tais como nas bordas dos fragmentos.

Palavras-chave: Efeito de borda, fitotelma, invertebrados, remanescentes florestais. 


\section{Introduction}

Bromeliads in neotropical forests serve as habitats for bacteria (Haubrich et al. 2009), algae (Brouard et al. 2011), fungi (Sophia 1999), protozoa (Foissner et al. 2003), arthropods and anuran amphibians (Benzing 1990, Silva et $a$ l. 2011). Some invertebrates, such as oligochaetes and ostracods, spend their entire lives inside the cisterns of bromeliads (Montero et al. 2010, Pinto \& Jocqué 2013), while others are only found in such habitats in immature forms, mainly beetles and flies (Mestre et al. 2001). These organisms play an important role (Sodré et al. 2010), by helping to degrade the organic matter falling from the forest canopy, accelerating the release of nutrients to the bromeliad (Benzing 1990, Richardson 1999, Armbruster et al. 2002, Araújo et al. 2007, Brouard et al. 2012). Furthermore, Martinelli et al. (2008) mentioned the ecological importance of bromeliads due to their interaction with fauna, making a considerable contribution of the biodiversity of the communities in which they live. Some endangered insect species in the Atlantic Forest use bromeliads as habitat for reproduction (De Marco-Júnior e Furieri 2000).

The reduction of forest habitats by human activities leads to landscapes formed of isolated fragments (Fahrig 2003), and consequently causes the isolation of populations, making species more vulnerable to hunting, competition with invasive species, predation and alterations in physical and chemical parameters (Laurance 1991, Murcia 1995, Dale et al., 2000, López-Barrera et al. 2005). This fragmentation interferes in the composition and distribution of the species along the edge gradient towards the center of the fragment (Ewers \& Didham 2006). Such alteration of forest habitats often occurs in short time intervals and impairs the evolutionary processes of species.

Although studies of bromeliads have shown high potential to understand the ecology of forested landscapes and the different compositions of the invertebrate communities in distinct landscapes (Yanoviak et al. 2006), information about the influence of habitat fragmentation on invertebrates that live inside bromeliads is still scarce in the literature. Minas Gerais, especially in the Mantiqueira and Serra mountain ranges, contains various remnant areas of Atlantic Forest and Cerrado, respectively, with a rich diversity of epiphytes, including some bromeliads considered in danger of extinction (Versieux \& Wendt 2007), whose tanks serve as habitat for diverse fauna. Hence, there is a need for studies in this region that can generate information to support measures to preserve bromeliad communities.

Animals that live in plants can be influenced by factors such as geography, environment and human activities (Kitching 2008). In the local context, the edge effect can lead to changes in the structure, composition and dynamics of populations of plants (Lima-Ribeiro 2008) and animals (Ewers \& Didham 2007). Based on these patterns, the aim of this study was to test the hypothesis that the populations of invertebrates that live in bromeliad tanks located near the edges of forest fragments have lower richness and diversity than those living in bromeliads within such fragments. Additionally, we tested whether the fauna in bromeliads located in native fragments near planted forests is less susceptible to the edge effects than those in a pasture matrix.

\section{Material and methods}

\section{Study area}

The study was carried out in 12 forest fragments located in the Serra da Mantiqueira range in the municipality of Bom Jardim, located in the state of Minas Gerais, southeastern Brazil (Figure 1), between the coordinates $21^{\circ} 54^{\prime} \mathrm{S} ; 4^{\circ} 05^{\prime} \mathrm{W}$ and $22^{\circ} 04^{\prime} \mathrm{S} ; 4^{\circ} 13^{\prime} \mathrm{W}$. In each fragment (In this study identified with the letter F) the number of bromeliads sampled varied according to the availability of these plants: F1 (12 sampled bromeliads), F2 (8 bromeliads), F3 (15 bromeliads), F4 (20 bromeliads), F5 (9 bromeliads),
F6 (13 bromeliads), F7 (16 bromeliads), F8 (9 bromeliads), F9 (15 bromeliads), F10 ( 7 bromeliads), F11 (15 bromeliads) and F12 ( 8 bromeliads), The two fragments nearest together (F9 and F10) are separated by approximately $120 \mathrm{~m}$, while the two furthest apart (F1 and F12) are about $21 \mathrm{~km}$ from each other. The altitude in the area ranges from 1,200 to $1,450 \mathrm{~m}$.

The remaining Atlantic Forest vegetation in the study area is composed of phytophysiognomies classified as dense high-montane ombrophilous forest or cloud forest, and by some rocky field areas. The matrixes adjacent to the fragments are composed of plantations of Pinus sp. or Eucalyptus sp., designated in the present study as planted forests, and pastures of Brachiaria sp. and molasses grass, Melinis minuflora Pall de Beauv.

\section{Sampling and identification of invertebrates}

The study was carried out between November 2012 and March 2013 (rainy season). The invertebrate specimens were sampled by suction, using a syringe with capacity of $50 \mathrm{ml}$, coupled to a hose with length of $50 \mathrm{~cm}$ and diameter of $5 \mathrm{~mm}$, from the lateral and central tanks of 147 bromeliads belonging to four morphospecies of the genus Vriesea Lindl (Bromeliaceae, Tillandsioideae). The size of the invertebrates collected was limited by the diameter of the hose attached to the syringe. The invertebrates that remained in the hose or did not pass through the syringe were disregarded. The most efficient way to overcome this limitation is to collect the bromeliad, but this is unsuitably invasive for these species, considering their slow growth, delay in flowering and scarcity.

Of the invertebrates sampled, 123 were located in fragments adjacent to pastures and 24 in fragments next to planted forest areas. To analyze the effect of distance from the edge on the bromeliad communities, we chose four fragments next to pastures: F1, F4, F7 and F11, whose widths in collection points varied from $100(\mathrm{~F} 4)$ to $1,700 \mathrm{~m}(\mathrm{~F} 11)$. In each of these, we established six sections according to the distance from the edge toward the center of the fragment: section A ( 0 to $13 \mathrm{~m})$, section B (14 to $24 \mathrm{~m}$ ), section C ( 25 to $35 \mathrm{~m})$, section D ( 36 to $56 \mathrm{~m})$, section $\mathrm{E}$ ( 80 to $117 \mathrm{~m}$ ) and section $\mathrm{F}$ (150 to $230 \mathrm{~m}$ ). We then randomly chose nine bromeliads in each of these sections.

The influence of the matrix (pasture or planted forest) was analyzed using the bromeliads found between 0 and $100 \mathrm{~m}$ from the edge of each fragment. We chose 16 bromeliads from the fragments neighboring planted forests (F3, F9 and F10) and 16 from the fragments next to pastures (F3, F4 and F8).

Water samples, varying in volume from 60 to $100 \mathrm{ml}$, were obtained from bromeliads whose bases were located between 0 and $1.9 \mathrm{~m}$ from the soil, with the use of a syringe connected to a hose. The specimens found in the water samples were fixed in $98^{\circ} \mathrm{GL}$ ethanol and were sorted and identified under a stereomicroscope. The invertebrates were identified to the family and subfamily level (except Annelida, Crustacea and Acari) using the keys in the literature: Merritt and Cummins (1996) for insects; Epler (2001) for Chironomidae, and Domínguez and Fernández (2009) for arthropods. Then the invertebrates were further analyzed at the Benthic Invertebrate Laboratory of Juiz de Fora Federal University (LIB/UFJF). After sorting the organisms to obtain the amount of organic material present in the samples, they were dried at $60{ }^{\circ} \mathrm{C}$ for 72 hours and then the material was weighed on an analytical balance (precision of $0.001 \mathrm{~g}$ ). Next, the samples were burned in a muffle furnace at $550{ }^{\circ} \mathrm{C}$ for 4 hours and again weighed. The amount of organic matter was obtained from the difference between the weight of the samples before and after burning (Suguio, 1973).

\section{Data analysis}

The abundance, taxon richness, Shannon diversity and Pielou evenness were calculated for the specimens obtained from each of the six bands in relation to the edges of the fragments and for the fragments next to pasture and planted forest. For this purpose we used the PAST program, version 2.10 (Hammer et al., 2001). 

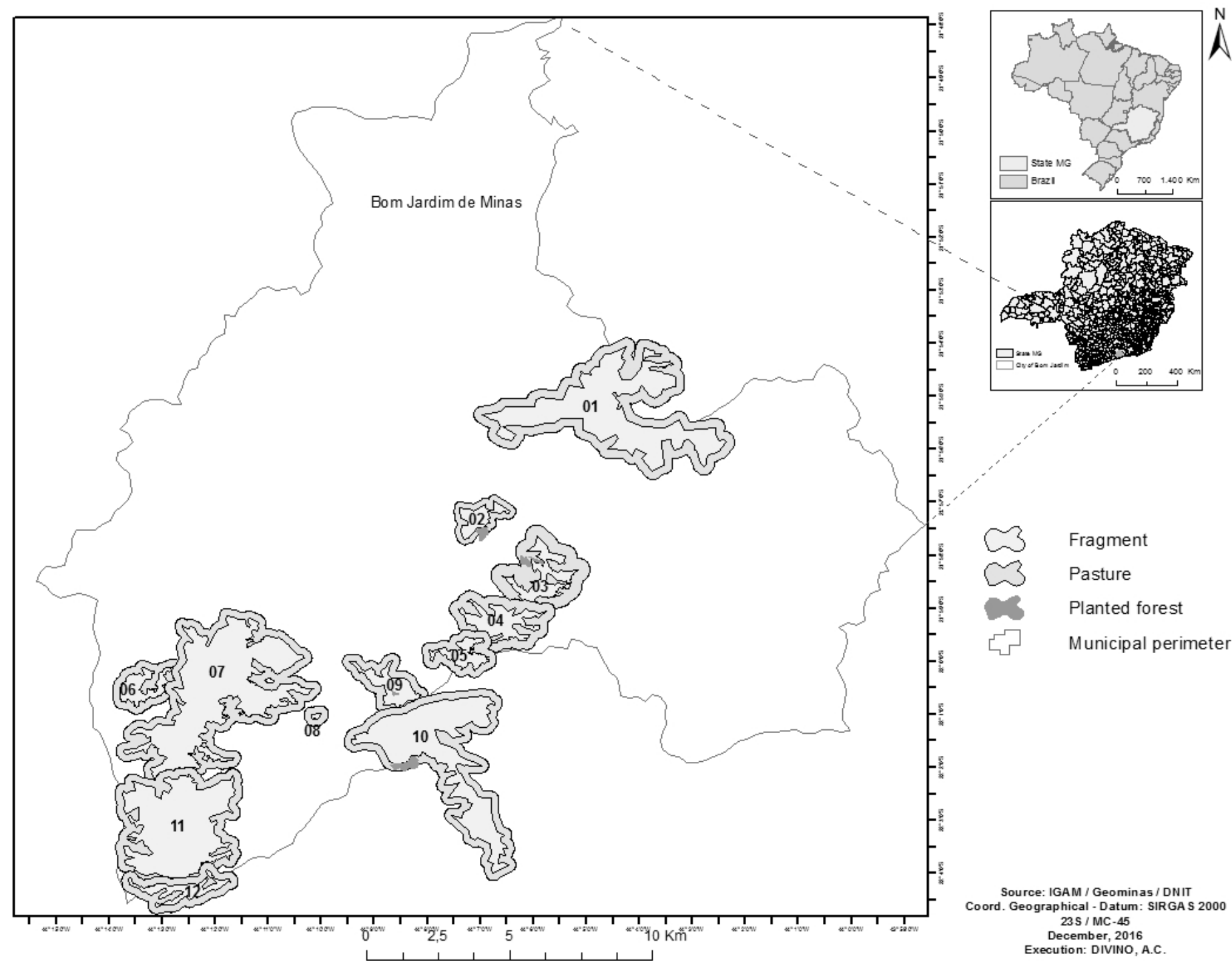

Figure 1: Map of Brazil indicating the Atlantic Forest fragments studied (F1 to F12) in the southeast of the state of Minas Gerais. The fragments shown have different sizes: F1(400 ha), F2 (120 ha), F3 (100 ha), F4 (150 ha), F5 (50 ha), F6 (50 ha), F7 (700 ha), F8 (0.5 ha), F9 (130 ha), F10 (350 ha), F11 (500 ha), F12 (100 ha).

The Kruskal-Wallis test $(\mathrm{p}<0.05)$ was used for comparison of the metrics among the distance bands from the edge, followed by multiple pairwise comparisons of the p-values. The Mann-Whitney test or t-test $(\mathrm{p}<0.05)$ was used to test differences in the metrics between the fragments located next to planted forest and pasture. Factorial ANOVA $(\mathrm{p}<0.05)$ was employed to test for effects of interaction between distance from edge (0 to $30 \mathrm{~m}$ or 50 to $100 \mathrm{~m}$ ) and adjacent matrix (planted forest or pasture) on the structure of the invertebrate fauna. Differences in the fauna composition among the four bromeliad morphospecies were checked by the multi-response permutation procedure (MRPP), since the intrinsic traits of each species can influence the differences in invertebrate fauna (Marino et al. 2013). This analysis was carried out with the PC-ORD 5.15 program (McCune \& Mefford, 2006).

Simple linear regression was used to analyze if the abundance, taxa richness and Shannon diversity were related directly to the distances of the bromeliads in relation to the fragment edge. This analysis was also used to determine if these same metrics had any relation with the organic matter content found in the tanks of each bromeliad. This analysis was performed with the Statistica 7.0 program (Statsoft, Inc. 2004).
The ordination analysis was performed to visualize whether the fauna composition changed as the location of the bromeliads became further from the edges of the fragments. For this purpose, the data were $\log$-transformed $[(\log (x+1)]$ and submitted to Detrended correspondence analysis (DCA). This same analysis was used to order the fauna according to the adjacent area (pasture or planted forest), using the log-transformed abundance data. Differences in the fauna composition between the sections sampled were also analyzed by MRPP. These analyses were performed using the PC-ORD 5.15 software (McCune \& Mefford, 2006). Analysis of similarity (ANOSIM) was used to test for significant differences in the taxa composition between the fragments next to planted forest and pasture. This analysis was carried out with the R program ( $\mathrm{R}$ Foundation for Statistical Computing 2011).

\section{Results}

In the 147 sampled bromeliads, 12,918 invertebrates were identified, represented by 35 taxa. The most abundant were Ostracoda (4,962 individuals), Culicinae $(2,358)$, Tanypodinae $(1,164)$ and Scirtidae $(1,043)$. The number of organisms per taxon is shown in Table 1. 
Table 1: Abundance of bromeliad invertebrates sampled in forest fragments in the municipality of Bom Jardim de Minas, Minas Gerais.

\begin{tabular}{|c|c|}
\hline Nematoda & 7 \\
\hline \multicolumn{2}{|l|}{ Annelida } \\
\hline Oligochaeta & 46 \\
\hline Hirudinea & 8 \\
\hline \multicolumn{2}{|l|}{ Crustacea } \\
\hline Copepoda & 195 \\
\hline Ostracoda & 2663 \\
\hline \multicolumn{2}{|l|}{ Arachnida } \\
\hline Acari & 59 \\
\hline \multicolumn{2}{|l|}{ Hexapoda } \\
\hline Collembola & 8 \\
\hline \multicolumn{2}{|l|}{ Insecta } \\
\hline \multicolumn{2}{|l|}{ Odonata } \\
\hline \multicolumn{2}{|l|}{ Zygoptera } \\
\hline Coenagrionidae & 2 \\
\hline Dicteriadidae & 41 \\
\hline \multicolumn{2}{|l|}{ Coleoptera } \\
\hline Dytiscidae & 2 \\
\hline Noteridae & 5 \\
\hline Hydraenidae & 6 \\
\hline Scirtidae & 721 \\
\hline Elmidae & 2 \\
\hline \multicolumn{2}{|l|}{ Diptera } \\
\hline Tipulidae sp1 & 23 \\
\hline Tipulidae sp2 & 2 \\
\hline Sciaridae & 5 \\
\hline Ceratopogonidae & 61 \\
\hline \multicolumn{2}{|l|}{ Chironomidae } \\
\hline Tanypodinae & 755 \\
\hline Chironominae & 190 \\
\hline Orthocladiinae & 173 \\
\hline \multicolumn{2}{|l|}{ Culicidae } \\
\hline Anophelinae & 336 \\
\hline Culicinae & 1498 \\
\hline Psychodidae & 179 \\
\hline Tabanidae & 4 \\
\hline Stratiomyidae & 9 \\
\hline Empididae & 52 \\
\hline Syrphidae & 3 \\
\hline Muscidae & 5 \\
\hline Total & 7218 \\
\hline
\end{tabular}

No significant changes were detected $(\mathrm{p}>0.05)$ in the abundance, taxon richness and diversity of invertebrates in bromeliads located different distances from the edges (Table 2).

Although not statistically significant ( $p>0.05)$, the greatest abundance of invertebrates was recorded in the fragments next to pasture areas and the highest richness was found in fragments adjacent to planted forest areas (Table 3).

The factorial ANOVA did not reveal a significant effect of the interaction between matrix (pasture or planted forest) and distance from the edge on the community of invertebrates found in the bromeliads: abundance $(\mathrm{F}=0.145$; $\mathrm{p}=0.745)$, taxon richness $(\mathrm{F}=0.001 ; \mathrm{p}=0.998)$ and Shannon diversity $(\mathrm{F}=0.290$; $\mathrm{p}=0.915)$. Regarding the fauna composition, no differences were detected among the bromeliad morphospecies (MRPP, $\mathrm{p}>0.05$ ).

The simple regression analysis did not reveal any relationship between the distance from the edge and abundance $\left(\mathrm{R}^{2}=0.006 ; \mathrm{F}=0.078 ; \mathrm{p}=0.779\right)$, taxon richness $\left(\mathrm{R}^{2}=0.005 ; \mathrm{F}=1.712 ; \mathrm{p}=0.193\right)$ and Shannon diversity $\left(\mathrm{R}^{2}=0.005 ; \mathrm{F}=0.413 ; \mathrm{p}=0.521\right)$. This same analysis also did not reveal any relation between the organic matter content of the cisterns and the community metrics: abundance $\left(\mathrm{R}^{2}=0.034 ; \mathrm{F}=0.031 ; \mathrm{p}=0.860\right)$, richness $\left(\mathrm{R}^{2}=0.035 ; \mathrm{F}=0.003 ; \mathrm{p}=0.953\right)$ and diversity $\left(\mathrm{R}^{2}=0.034 ; \mathrm{F}=0.039 ; \mathrm{p}=0.843\right)$.

The DCA did not reveal any distinction of the fauna composition between the sections located at different distances from the fragment edge (Figure 2). The MRPP analysis distinguished the fauna composition between only some of these sections, regardless of distance from the edge (Table 4).

The detrended correspondence analysis (DCA) did not show any distinction in the fauna composition between the samples from fragments next to planted forest and pasture (Figure 3). This result was confirmed by the analysis of similarity (ANOSIM), which did not show a significant variation in the taxon composition $(\mathrm{p}>0.05)$ between the two matrixes.

\section{Discussion}

In general, the composition of invertebrates found in this study was similar to those found in other studies investigating the fauna of bromeliads in different regions of Brazil (Lopez 1998, Araújo et al. 2007, Marques et al. 2008, Sodré 2010). This result corroborates Mestre et al. (2000), who indicated the possible existence of a characteristic bromeliad fauna associated with these plants, permanent and transitory, but with a predominance of some groups adapted to changes in the chemical composition and input of nutrients to the bromeliads (Schuttz et al. 2012). According to Franck (1983), many endemic invertebrate species are specialized in this micro-environment. On the other hand, some organisms only are accidentally found in bromeliads, using the plants as temporary refuge (Armbruster et al., 2002), especially in areas where the external

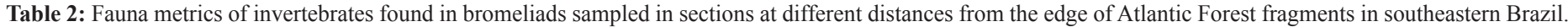

\begin{tabular}{|c|c|c|c|c|c|c|c|}
\hline & \multicolumn{6}{|c|}{ Distance from the edge (m) } & \multirow{2}{*}{ Statistic } \\
\hline & Up to 13 & 14 to 24 & 25 to 35 & 36 to 56 & 80 to 117 & 150 to 230 & \\
\hline Abundance & 667 & 1578 & 593 & 249 & 502 & 605 & $\mathrm{~F}=0.794 ; \mathrm{p}=0.558$ \\
\hline Richness & 19 & 22 & 23 & 17 & 19 & 17 & $H=7.985 ; p=0.157$ \\
\hline Equitability & 0.74 & 0.69 & 0.7 & 0.75 & 0.74 & 0.74 & $F=0.475 ; p=0.793$ \\
\hline Shannon & 1.42 & 1.25 & 1.51 & 1.32 & 1.49 & 1.52 & $F=0.608 ; p=0.693$ \\
\hline
\end{tabular}

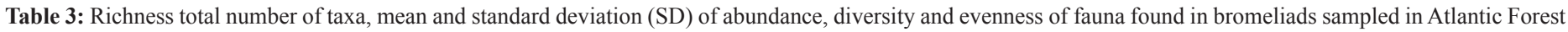
fragments in southeastern Brazil, according to neighboring matrix (planted forest or pasture).

\begin{tabular}{|c|c|c|c|c|c|}
\hline & \multicolumn{2}{|c|}{ Planted Forest SD } & \multicolumn{2}{|c|}{ Pasture SD } & \multirow{2}{*}{$\begin{array}{c}\text { Statistic } \\
\mathrm{t}=-1.145 ; \mathrm{p}=0.341\end{array}$} \\
\hline Richness total & 24 & & 23 & & \\
\hline Mean abundance & 88.13 & \pm 67.39 & 123.31 & \pm 124.48 & $\mathrm{t}=-0.744 ; \mathrm{p}=0.458$ \\
\hline Shannon & 1.42 & \pm 0.29 & 1.35 & \pm 0.45 & $Z=-0.705 ; p=0.480$ \\
\hline Equitability & 0.69 & \pm 0.17 & 0.69 & \pm 0.20 & $Z=1.586 ; p=0.112$ \\
\hline
\end{tabular}


environment is less favorable to the development and survival of these organisms (Oliveira et al., 1994).

Unlike our initial hypothesis that the richness and diversity of bromeliad fauna of the fragment edge are more vulnerable to the effects of environmental conditions at these sites, our results showed no significant differences in

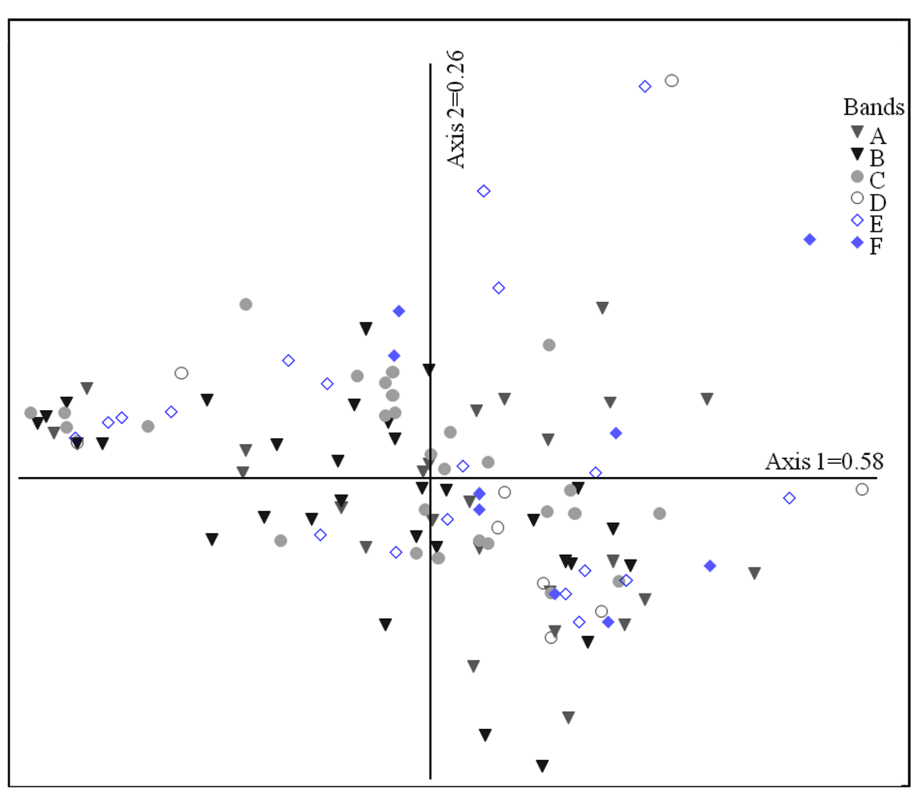

Figure 2: Results of the detrended correspondence analysis (DCA) of invertebrate fauna in bromeliads collected in sections at different distances from the edge of Atlantic Forest fragments in southeastern Brazil. $A=$ up to $13 \mathrm{~m}, \mathrm{~B}=14$ to $24 \mathrm{~m}$, $\mathrm{C}=25$ to $35 \mathrm{~m}, \mathrm{D}=36$ to $56 \mathrm{~m}, \mathrm{E}=80$ to $117 \mathrm{~m}$ and $\mathrm{F}=150$ to $230 \mathrm{~m}$.

Table 4: Results of the MRPP analysis of fauna found in bromeliads sampled in sections at different distances from the edge of Atlantic Forest fragments in southeastern Brazil.

\begin{tabular}{cccccc}
\hline & Sections & & T & A & p \\
\hline A & vs. & C & -1.815 & 0.028 & 0.050 \\
C & vs. & D & -2.656 & 0.043 & 0.016 \\
D & vs. & F & -2.491 & 0.035 & 0.017 \\
\hline
\end{tabular}

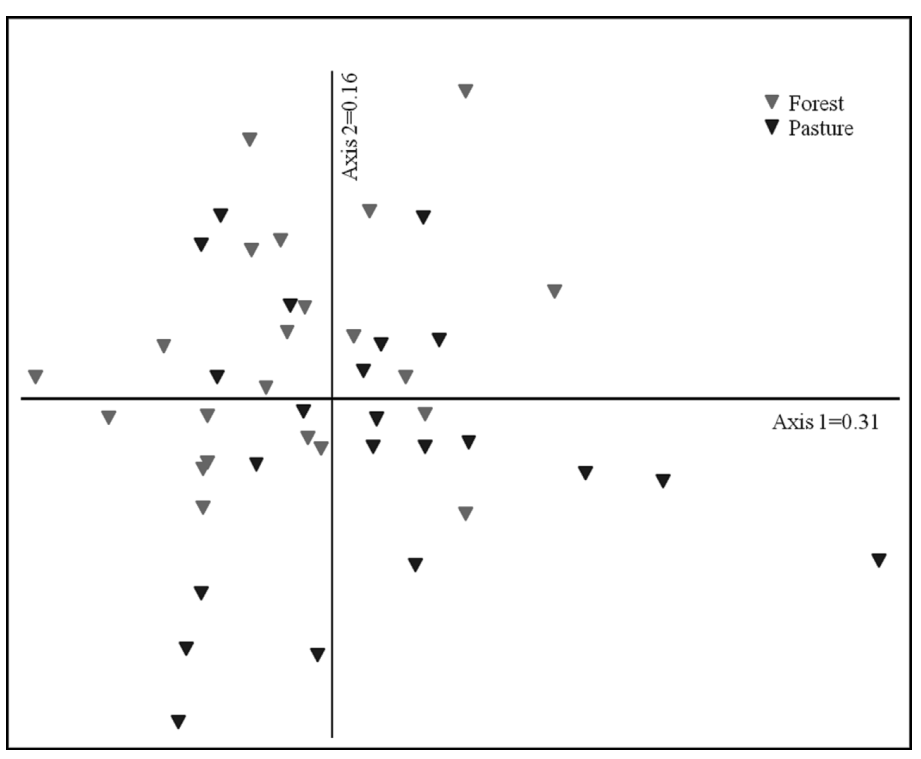

Figure 3: Results of the detrended correspondence analysis (DCA) of invertebrate fauna found in bromeliads sampled in Atlantic Forest fragments in southeastern Brazil, next to pasture or planted forest. the composition, richness and diversity of the communities near the edge or inside the fragments. This result can be a reflection of the low stature of the high-montane vegetation, (Meireles et al. 2008) and of the elongated shape of the fragments (whose width in collection points varied from $100 \mathrm{~m}$ (F1) to 1,700 m (F11), making the environmental conditions (e.g., wind, sunlight, input of plant material) in the interior sections similar to those near the edges, and therefore insufficient to promote dissimilarities in the structure of the invertebrate community found in bromeliads situated at different distances from the edges.

Similar environmental conditions can also explain the absence of significant differences in the composition, richness and diversity of invertebrates in the fragments adjacent to both landscapes (planted forest or pasture). The terrain, marked by high declivity, could have influenced this result, since the bromeliads were often located on hillsides above the canopy of planted forests, and thus were subject to similar conditions to those found in the fragments next to pastures. On the other hand, it is possible that the habitat of the bromeliad itself softens the adverse effects of location near the edge of fragments, by providing protection against external factors such as wind and heat. Oliveira et al. (1994), for example, indicated that bromeliads in coastal marshland are used by meso and microscopic fauna due to the moisture and protection against heat of the biome, besides the shelter from predators. In turn, Marques et al. (2008), comparing the fauna of Culicidae (Diptera) from terrestrial bromeliads, found similar richness and species diversity among urban, semi-urban and forest environments.

Considering bromeliads 'per se', among the factors that influence the fauna that find shelter in these plants is the quantity to organic detritus (food) and volume of water, both of which contribute to increase the abundance and richness of morphospecies of invertebrates, as found by Armbruster et al. (2002). The food that is available has a strong effect on the richness of morphospecies within the plant, while the volume of water in the tanks favors the presence of organisms that are not suited to living in dry plants, besides increasing the heterogeneity of the habitat. However, we did not detect any relation between the quantity of detritus in the bromeliads and the abundance and richness of invertebrates. This might have occurred because those authors considered all the material accumulated in the bromeliads, while we set a maximum limit on the material collected. In turn, the absence of differences in the fauna composition between the morphospecies of bromeliads probably occurred because they had similar architecture with respect to cistern size. This aspect can result in similar quantities of food resources for the fauna (Marino et al., 2013), explaining the absence of differences in the composition of invertebrates.

With respect to the predominance of some groups in the bromeliads, Ostracoda was the most abundant taxon, as also observed by Lopez et al. (1999) in bromeliads from Atlantic Forest fragments in the state of Rio de Janeiro. Among the insects collected, the majority belonged to the sub-order Nematocera (Diptera), which is associated with moist environments (Grimaldi \& Engel, 2005) because their reproduction depends on the availability of water reservoirs for larval development. Culicidae was the most abundant family in all the bromeliads, corroborating the findings of Hilsenhoff (1991), Araújo et al. (2007), and Parker et al. (2012), all of whom observed this family, along with the Chironomidae, to be among the most abundant phytotelma insects. In this study, Chironomidae was represented mainly by the sub-family Tanypodinae, a result that differs from that reported by Sodré (2010) in Atlantic Forest areas of Rio de Janeiro. In both of these cases the authors found the greatest abundance of larvae of the sub-family Orthocladiinae in bromeliads. In turn, Scirtidae (Coleoptera), also abundant in this study, was the most numerous insect family found by Mestre et al. (2001) among insects from bromeliads in an Atlantic Forest area of the state of Paraná. According to Oliveira et al. (1994), the different predominance of some groups in bromeliads reflects local differences in the organization of bromeliad communities 


\section{Conclusions}

In conclusion, in the forest fragments investigated, bromeliads proved to be a favorable habitat for invertebrate fauna, so we suggest they be included in policies to protect biodiversity, not only for their floristic richness, but also their importance in maintaining the richness and diversity of invertebrates that use them for shelter, even in altered landscapes exposed to adverse conditions, such as the borders of forest fragments.

\section{Acknowledgments}

We would like to thank Fundação de Amparo à Pesquisa do Estado de Minas Gerais (FAPEMIG) for the financial support and Conselho Nacional de Desenvolvimento Científico e Tecnológico (CNPq) for ongoing support (grant numbers 303156/2012-0). The second author is grateful to Coordenação de Aperfeiçoamento de Pessoal de Nível Superior (CAPES) for research grant.

\section{References}

ARAÚJO, V.A., MELO, S.K., ARAÚJO, A.P.A., GOMES, M.L.M. \& CARNEIRO, M.A.A. 2007. Relationship between invertebrate fauna and bromeliad size. Braz. J. Biol. 67 (4): 611-617.

ARMBRUSTER, P., HUTCHINSON, R.A. \& COTGREAVE, P. 2002. Factors influencing community structure in a South American tank bromeliad fauna. Oikos. 96: 225-234. DOI:10.1034/j.1600-0706.2002.960204.x

BENZING, D.H. 1990. Vascular epiphytes: general biology and related biota. Cambridge University Press.

BROOKS, T.M., MITTERMEIER, R.A., MITTERMEIER, C.G., FONSECA, G.A.B., RYLANDS, A.B., KONSTANT, W.R., FLICK, P., PILGRIM, J., OLDFIELD, S., MAGIN, G. \& HILTON-TAYLOR, C. 2002. Habitat loss and extinction in the hotspots of biodiversity. Conserv. Biol. 16(4): 909-923. DOI: 10.1046/j.1523-1739.2002.00530.x

BROUARD, O., LE JEUNE, A-H., LEROY, C., CEREGHINO, R., ROUX, O., PELOZUELO, L., DEJEAN, A., CORBARA, B. \& CARRIAS, J-F. 2011. Are algae relevant to the detritus-based food web in tank-bromeliads?. PloS ONE, 6 (5): e20129. DOI:10.1371/journal.pone.0020129

BROUARD, O., CEREGHINO, R., CORBARA, B., LEROY, C., PELOZUELO, L., DEJEAN, A. \& CARRIAS, J. F. 2012. Understorey environments influence functional diversity in tank-bromeliad ecosystems. Freshwater Biol. 57: 815823. DOI: 10.1111/j.1365-2427.2012.02749.x

DALE, S., MORK, K., SOLVANG, R. \& PLUMPTRE, A.J. 2000. Edge effects on the understory bird community in a logged forest in Uganda. Conserv. Biol. 14(1): 265-276. DOI: 10.1046/j.1523-1739.2000.98340.x

DOMÍNGUEZ, E. \& FERNÁNDEZ, H.R. 2009. Macroinvertebrados bentónicos sudamericanos. Sistemática y biología. Fundación Miguel Lillo, Tucumán, Argentina.

EPLER, J.H. 2001. Identification Manual for the Larval Chironomidae (Diptera) of North and South Carolina. A guide to the taxonomy of the midges of the southeastern United States, including Florida. Special Publication SJ2001-SP13.

EWERS, R. M., \& DIDHAM, R. K. 2007. The effect of fragment shape and species' sensitivity to habitat edges on animal population size. Conservation Biology, 21(4), 926-936.

EWERS, R.M. \& DIDHAM, R.K. 2006. Continuous response functions for quantifying the strength of edge effects Journal of Applied Ecology 43: 527-536.

FAHRIG, L. 2003. Effects of habitat fragmentation on biodiversity. Annu. Rev. Ecol. Evolut. Syst. 34: 487-515.

FOISSNER, W., STRÜDER-KYPKE, M., STAAY, G.W.M., STAAY, S.M. \& HACKSTEIN, J.H.P. 2003. Endemic ciliates (Protozoa, Ciliophora) from tank bromeliads (Bromeliaceae): a combined morphological, molecular, and ecological study. Eur. J. Protistol. 39: 365-372. DOI:10.1078/0932-4739-00005

FRANK, J. H. 1983. Bromeliad phytotelmata and their biota, especially mosquitoes. Phytotelmata: terrestrial plants as hosts for aquatic insect communities, 101-128.
GRIMALDI, D. A. \& ENGEL, M. S. 2005. Evolution of the insects. Cambridge, UK; New York, NY: Cambridge University Press

HAMMER, O., HARPER, D.A.T \& RYAN, P.D. 2001. PAST: Paleontological Statistics software package for education and data analysis. Version 2.10. Paleontologia Eletronica 4(1):9.

HAUBRICH, C.S., PIRES, A.P.F., ESTEVES, F.A. \& FARJALLA, V.F. 2009. Bottom-up regulation of bacterial growth in tropical phytotelm bromeliads. Hidrobiologia. 632: 347-353. DOI: 10.1007/s10750-009-9841-6

HILSENHOFF, W.L. 1991. Diversity of insects and Collembola. In: Thorp, J.H. and Covich, A.P. (eds.). Ecology and classification of north american freshwater invertebrates. Academic Press, New York, p. 661-731.

LAURANCE, W.F. 1991. Edge effects in tropical forest fragments: application of a model for the design of nature reserves. Biol. Conserv. 57: 205-219. DOI:10.1016/0006-3207(91)90139-Z

LÓPEZ-BARRERA, F., NEWTON, A. \& MANSON, R. 2005. Edge effects in a tropical montane forest mosaic: experimental tests of post-dispersal acorn removal Ecological Research 20: 31-40.

LOPEZ, L.C.S., D’ELIAS, A.M.A. \& RIOS, R.I. 1998. Fatores que controlam a riqueza e a composição da fauna aquática em tanques de bromélia Aechmea bromeliifolia (Rudge) Baker, na restinga de Jacarepiá - Saquarema/RJ. Oecol. Bras. 5: 91-100.

LOPEZ, L.C.S., RODRIGUES, P.J.F.P. \& RIOS, R.I. 1999. Frogs and Snakes as Phoretic Dispersal Agents of Bromeliad Ostracods (Limnocytheridae: Elpidium) and Annelids (Naididae: Dero). Biotropica 31(4): 705-708.

MARINO, N.A.C., SRIVASTAVA, D.S. \& FARJALLA, V.F. 2013. Aquatic macroinvertebrate community composition in tank-bromeliads is determined by bromeliad species and its constrained characteristics. Insect Conserv. Diversity. 6: 372-380. DOI: 10.1111/j.1752-4598.2012.00224.x

MARQUES, G.R.A.M. \& FORATTINI, O.P. 2008. Culicídeos em bromélias: diversidade de fauna segundo influência antrópica, litoral de são paulo. Rev. Saúde Públ. 42(6): 979-85.

MCCUNE, B. \& MEFFORD, M.J. 2006. PC-Ord for Windows v. 5.15. Multivariate Analysis of Ecological Data. MjM Software, Gleneden Beach OR, USA.

MEIRELES, L.D., SHEPHERD, G.J. \& KINOSHITA, L.S. 2008. Variações na composição florística e na estrutura fitossociológica de uma floresta ombrófila densa alto-montana na Serra da Mantiqueira, Monte Verde, MG. Rev. Bras. Bot. 31(4): 559-574.

MESTRE, L.A.M., ARANHA, J.M.R. \& ESPER, M.L.P. 2001. Macroinvertebrate fauna associated to the bromeliad Vriesea inflata of the Atlantic Forest (Paraná State, Southern Brazil). Braz. Arch. Biol. Technol. 44(1): 89-94.

MERRITT, R.W. \& CUMMINS, K.W. (editors). 1996. An introduction to the aquatic insects of North America, 3rd ed.Kendall/Hunt Publishing Company, Dubuque, Iowa.

MONTERO, G., FERUGLIO, C. \& BARBERIS, I.M. 2010. The phytotelmata and foliage macrofauna assemblages of a bromeliad species in different habitats and seasons. Insect Conserv. Divers. v. 3: 92-102. doi: 10.1111/j.17524598.2009.00077.x

MURCIA, C. 1995. Edge effects in fragmented forests: implications for conservation. Tree. 10(2): 58-62.

NUNES, J.V.C. Bromélias, In: L. L. SIMÕES \& C. F. LINO (Eds.). 2002. Sustentável Mata Atlântica: A exploração de seus recursos florestais. SENAC, São Paulo, Brasil. p. 119-132.

OLIVEIRA, M. O. N., ROCHA, C. F. D. \& BAGNALL, T. 1994. Bromélias-tanque servem de abrigo para espécies. Ciência Hoje 17(97):21-2.

PARKER, D.M., ZAVORTINK, T.J., BILLO, T.J., VALDEZ, U. \& EDWARDS, J.S. 2012. Mosquitoes and other arthropod macro fauna associated with tank bromeliads in a Peruvian cloud forest. J. Am. Mosq. Control Assoc. 28(1): 45-46. DOI: http://dx.doi.org/10.2987/11-6189.1

PINTO, R.L. \& JOCQUÉ, M. 2013. A new species of Elpidium (Crustacea, Ostracoda) from bromeliads in Cusuco National Park, Honduras. Zookeys, 313: 45-59. DOI: 10.3897/zookeys.313.4904

RICHARDSON, B.A. 1999. The Bromeliad Microcosm and the assessment of faunal diversity in a neotropical forest. Biotropica, 31(2): 321-336. DOI: 10.1111/j.1744-7429.1999.tb00144.x 
RODRIGUES, P.J.F.P. \& NASCIMENTO, M.T. 2006. Fragmentação florestal: breves considerações teóricas sobre efeitos de borda. Rodriguésia 57(1): 63-74.

SUGUIO, K., \& SUGUIO, K. 1973. Introdução à sedimentologia (No. 552.5 SUG).

SILVA, H.R., CARVALHO, A.L.G. \& BITTENCOURT-SILVA, G.B. 2011. Selecting a hiding place: anuran diversity and the use of bromeliads in a threatened coastal sand dune habitat in Brazil. Biotropica. 43(2): 218-227. DOI: 10.1111/j.17447429.2010.00656.x

SODRÈ, V.M., ROCHA, O. \& MESSIAS, M.C. 2010. Chironomid larvae inhabiting bromeliad phytotelmata in a fragment of the Atlantic Rainforest in Rio de Janeiro State. Braz. J. Biol. 70(3): 587-592.

SOPHIA, M.G. 1999. Desmídias de ambientes fitotélmicos bromelícolas. Rev. Bras. Biol. 59(1): 141-150.

STATSOFT, INC. Statistica (data analysis software system), version 7.0, 2004.

SCHUTTZ, R., ARAÚJO, L. C., \& SÁ, F. 2012. Bromélias: abrigos terrestres de vida de água doce na floresta tropical. Natureza, 10, 89-92.
TURNER, I.M. 1996. Species loss in fragments of tropical rain forest: a review of the evidence. J. Appl. Ecol. 33(2): 200-209.

VERSIEUX, L.M, \& WENDT, T. 2007. Bromeliaceae divertsity and conservation in Minas Gerais state, Brazil. Biodivers. Conserv. 16: 2989-3009. DOI: 10.1007/ s10531-007-9157-7

YANOVIAK, S.P., LOUNIBOS, L.P. \& WEAVER, S.C. 2006. Land use affects macroinvertebrate community composition in phytotelmata in the Peruvian Amazon. Conserv Biol Biodivers. 99(6): 1172-1181, DOI: http://dx.doi. org/10.1603/0013-8746(2006)99[1172:LUAMCC]2.0.CO;2

Received: 02/04/2016

Revised: 08/01/2017

Accepted: 18/01/2017

Published online: 09/02/2017 